\title{
The University of Tokyo: The Graduate School Reformation Project
}

Wataru Mori

Discussing the many changes in Japan during the Meiji modernization, Reischauer and Craig (1973, p. 164) wrote the following:

The Confucian-oriented domain schools for the samurai and the so-called 'temple schools' (for commoners) ... all withered away. The only exceptions were the shogunal schools. The Confucian 'University' in Edo, the medical school, and the language programme at the Institute for the Study of Barbarian Books were united in 1869 into a single government institution. The non-Western aspects of the curriculum were dropped in 1871, and in 1877 the school was renamed Tokyo University under which name it has remained ever since the pinnacle of the Japanese educational system.

A 'pinnacle' though it may be in Japan, Tokyo University, as with universities worldwide, has many problems. For example, my work on the graduate school reformation project can provide some insight into the unique characteristics of Japanese higher education. This example can also show why university presidents must maintain a long-range perspective if they hope to accomplish their highest institutional goals. For greater background and details, reference may be made to Tokyo University (1992).

Since graduate schools only developed substantially at Japanese universities after the Second World War, confusion has gradually grown out of the following vices to counter the development of graduate systems of higher education, as is the case at Tokyo University:

1. thirty years since their foundation, graduate schools have not been institutionalized with standing staff and faculty;

2. as postgraduate enrolments have gradually increased, the number of graduate students exceeds undergraduates in some disciplines;

3. graduate school budgets are meagrely funded.

At first, we tried to overcome such problems through administrative contrivances, but the problems have outgrown simple steps and solutions today at Japan's leading institutions, where research supposedly takes priority. It is my personal opinion that the attitude of the Japanese Government, in particular the Ministry of Education, towards higher education values undergraduate education rather than academic research. Thus, the government wants to regard all universities in Japan as equivalents rather than as diverse institutions with different clients and missions, eg undergraduate versus graduate education and research. National policy-making on such precepts illustrates how anachronisms can hinder higher education.

Appointed Tokyo University President in 1985, I decided to give priority to graduate school reform during my term of office. The University's Constitution limits the president to only one term of four years. Together with many others, we formulated a strategy to convert the faculty (or departmental) oriented system to a graduate school oriented system. The core of that strategy embodied the following four points.

1. Recognizing that Tokyo University's most important contributions in education and research would be better realized through a university graduate system, we attempted to reshape the University's management and finances to accommodate the desired objectives.

2. In so doing, however, we did our best to respect the histories and traditions of university faculties and research institutions and seek their close cooperation and university consensus.

3. We argued that Tokyo University's mission was to foster world class research and promote the endeavours of researchers and specialists. This mission distinguished the University and its calibre from others and would be best actualized through a new graduate school structure.

4. In terms of heavy social demands for higher education in Japan, a clear change in structure was needed to overcome basic contradictions between Tokyo University's mission and contrasting expectations. One thing that was sure was that our objectives could not be accomplished with undergraduate-level education, and faculty had to enrich and expand specialist and professional training and stress meaningful articulation between undergraduate and graduate levels.

Four years as Tokyo University's president was not enough time to plan and prepare the strategy for the graduate school project, to persuade the many faculties, to convince the Ministry of Education, and to complete all that was needed to bring about such changes. It was then necessary to pass such a massive institutional project over to my successor who, as the case may be, would have the problems and ongoing projects to relay on to later Tokyo presidents. I am pleased to report that Professor Akito Arim, the current president of the University of Tokyo, fully supports the Graduate School Reformation Project and has successfully moved it along. At present, the Tokyo University Faculties of Law, Science and Engineering are actualizing the structural reforms. In the near future the movement will have progressed to such an extent that the University of Tokyo as a whole will be reorganized into the graduate school format.

\section{REFERENCES}

Reischauer, E.O. and Craig, A.M. (1973) Fapan: Tradition and Transformation, New York, Houghton Mifflin.

Tokyo University (1992) Tokyo University - The Present Status and Its Tasks $I$, Tokyo, Tokyo University Press (in Japanese). 